\title{
Serum Sex Hormonal Responses to Acute Oral Cadmium Exposure of Male Wistar Rats
}

\author{
Otamere $\mathrm{HO}^{1 *}$, Akpamu $\mathrm{U}^{2}$, Osifo $\mathrm{UC}^{1}$ and Aigberemolen $\mathrm{A}^{1}$ \\ ${ }^{1}$ Department of Physiology, Faculty of Basic Medical Sciences, College of Medicine, Ambrose Alli University, Ekpoma, Nigeria \\ ${ }^{2}$ Gastrointestinal Secretory and Inflammatory Unit, Department of Physiology, Faculty of Basic Medical Sciences, College of \\ Medicine, University of Ibadan, Ibadan-Nigeria
}

*Corresponding author: Otamere HO, Department of Physiology, Faculty of Basic Medical Sciences, College of Medicine, Ekpoma, Nigeria

ARTICLE INFO

Received: 熭 July 17, 2020

Published: 幽 July 28, 2020

Citation: Otamere HO, Akpamu U, Osifo UC, Aigberemolen A. Serum Sex Hormonal Responses to Acute Oral Cadmium Exposure of Male Wistar Rats. Biomed J Sci \& Tech Res 29(2)-2020. BJSTR. MS.ID.004763.

Keywords: Cadmium; Sex Hormones; Male Fertility

\section{ABSTRACT}

The objective of this study is to investigate the possible effects of cadmium (Cd) exposure on the serum levels of sex hormones in male Wistar rats. Twenty rats were grouped into four and treated with $\mathrm{Cd}$ as follows; control (unexposed) and groups 2, 3 and 4 were exposed to $10 \mathrm{ppm}, 100 \mathrm{ppm}$ and $1000 \mathrm{ppm} \mathrm{Cd}$ respectively for 7 days through contamination of their drinking water. Blood samples were collected for the determination of sex hormones via enzyme immunoassays and the obtained data statistically compared. There was a significant increase in blood Cd level in the $100 \mathrm{ppm}$ $(0.0153 \pm 0.0085 \mathrm{ppm})$ and $1000 \mathrm{ppm}(0.0298 \pm 0.0204 \mathrm{ppm})$ exposed groups compared to control $(0.0008 \pm 0.0005 \mathrm{ppm})$. The results showed a dose-response increase in serum leutinizing hormone $(2.10 \pm 0.12 ; 2.29 \pm 0.26 ; 2.22 \pm 0.37 ; 3.18 \pm 0.54) \mathrm{g} / \mathrm{L}$ and follicle stimulating hormone $(1.63 \pm 0.40 ; 2.40 \pm 0.32 ; 3.09 \pm 0.10 ; 3.81 \pm 0.36) \mathrm{g} / \mathrm{L}$ but decrease in serum testosterone $(4.62 \pm 0.490 ; 2.87 \pm 0.47 ; 2.10 \pm 0.18 ; 1.57 \pm 0.32) \mathrm{ng} /$ $\mathrm{ml}$ in that order in the unexposed group compared to the Cd-exposed groups. Oral Cd exposure can be a critical determinant of sex hormone homeostasis in male rats and its influence in the animal fertility is not unlikely.

\section{Introduction}

Cadmium (Cd) is a toxic, extensive and persistent metal in the environment and modern civilization processes have contributed to it increase in the environment and has led to its rising occurrence in the food chains [1]. This metal has been placed 7th on the list of substances that pose potential threat to human health due to their known or suspected toxicity [2]. Industrially, Cd is used in a variety of manufactured products resulting in the increased bioaccessibility, and anthropogenic sources are the most significant threat to human health $[1,3]$. Exposure to Cd can occur through smoking, contaminated food, water and air $[4,5]$. The European Food Safety Authority (EFSA) estimated between 20.3 and $74.2 \mu \mathrm{g} /$ day as the average daily dietary exposure of $\mathrm{Cd}$ for a $70 \mathrm{~kg}$ person [5] and children and vegetarians have been noted as specific groups at risk of consuming higher dietary Cd than the recognized safe dose [6]. Due to lower concentrations of iron in women, they are thought to be at greater risk of increased $\mathrm{Cd}$ accumulation than males $[7,8]$.
$\mathrm{Cd}$ accumulates in the kidney, liver and the reproductive organs [9]. For this reason, Cd is categorized as environmental endocrine disruptors because it alters endocrine system function(s) and consequently cause adverse endocrine related health effects [10]. The endocrine disrupting effect of Cd has been extensively investigated but the outcomes are both agonistic [11-14] and antagonistic [14-16]. Chronic Cd exposures has been reported to disturbed reproductive endocrine function, cause testes degeneration, decrease testicular mass [17-19], and decreased spermatozoa mobility [20] in male rats. Studies in female rats showed $\mathrm{Cd}$ accumulates in the female reproductive organs [9,14,21-24]. In vivo studies have shown Cd administration to cause histopathological alterations in the ovary and uterus that include corpus luteum and granulosa cells degeneration, deceased oocytes population, increased luminal epithelial height and endometrial thickness $[1,25,26]$ and disturbances in the concentrations of 
circulating steroid hormones and estrous cycle abnormalities [1,21]. On the other hand, Johnson et al. [12] documented Cd exposure to produced uterine hyperplasia, increased mammary glands growth, and hormone-regulated genes induction in ovariectomized rats.

$\mathrm{Cd}$ has also been reported to shows androgen-like activities in vitro and in vivo, and it disrupts the male endocrine system in animal models [4]. There are however conflicting results regarding Cd increases or decreases testosterone production in experimental models [27-29], with decreases more commonly seen after a single, large dose injection of cadmium and increases more commonly seen after chronic oral cadmium exposure [30]. In human, studies investigating the association of $\mathrm{Cd}$ and sex steroid hormones in men have been inconsistent with either no association [31-33], or a positive association between cadmium and testosterone levels [34-36]. Due to the paucity of literature on the effect of $\mathrm{Cd}$ on male sex hormone levels, this study investigates the changes in the reproductive hormones of adult male Wistar rats following acute oral exposure.

\section{Materials and Methods}

\section{Materials}

Cadmium chloride $\left(\mathrm{CdCl}_{2}\right)$ was obtained from a Chemical store in Nigeria. All other chemicals were of analytical grade. The rat chow was obtained from a poultry store in Ekpoma, Nigeria. Except otherwise stated, the drinking water supplied was clean tap water.

Animals: Twenty male Wistar rats, weighing $140 \mathrm{~g}$ to $160 \mathrm{~g}$ were obtained from the Animal House, College of Medicine, Ambrose Alli University, Ekpoma. The rats were transported and kept in their own cages in the physiology laboratory II and maintained in a room with 12-hour light/dark cycle. They were fed standard rat chow and water ad libitum for a two-week period of acclimatization.

Study Design: After acclimatization, the rats were randomly assigned to four experimental groups, $(n=5)$ as follows: Group 1 ; served as the control group and was supplied clean tap water throughout the experiment. Group 2, 3 and 4 served as test groups and were served drinking water contaminated with cadmium chloride in the concentration of $10 \mathrm{ppm}, 100 \mathrm{ppm}$, and $1000 \mathrm{ppm}$, respectively. All animal had access to normal meal and drinking water throughout the study period.

Sample Collection: At the end of the 7th day, blood sample (3ml) was collected into two separate plain containers (each containing $1 \mathrm{ml}$ and $2 \mathrm{ml}$ ) via cardiac puncture after animals were cervically decapitated after ketamine/ zylazine anesthesia. The $1 \mathrm{ml}$ blood samples were digested with $\mathrm{HNO}_{3}$ and blood Cd level determined by atomic absorption spectrophotometer as documented by Goncalves et al. [37]. The $2 \mathrm{ml}$ blood samples were spin at 5000rpm for 15 minutes and the serum obtained placed in plain containers and refrigerated until assay. FSH, $\mathrm{LH}$ and testosterone concentrations were measured using ELISA kits (Biocheck, Inc, USA) and according to manufacturer's instructions.

Statistical Analysis: Statistical analyses were performed using "tools" from the SPSS version 20.0 programme. The data was subjected to one-way analysis of variance (ANOVA) and LSD post hoc test was used for multiple comparisons and expressed as mean \pm standard deviation; $\mathrm{p}<0.05$ was considered significant.

\section{Results}

Table 1 shows the effect of $\mathrm{Cd}$ exposure in drinking water on blood Cd-level of the experimented animals. The exposure to varying concentration of Cd caused a dose-dependent increase in blood $\mathrm{Cd}$ levels and significant in the $100 \mathrm{ppm}(0.0153 \pm 0.0085 \mathrm{ppm})$ and $1000 \mathrm{ppm}(0.0298 \pm 0.0204 \mathrm{ppm})$ groups compared to the control $(0.0008 \pm 0.0005 \mathrm{ppm})$. Figures $1-3$ shows the effect of $\mathrm{Cd}$ exposure in drinking water on serum FSH, LH and T respectively. There was a dose dependent significant increase in serum FSH $(1.63 \pm 0.40$ $\mathrm{g} / \mathrm{L}$ vs $2.40 \pm 0.32 \mathrm{~g} / \mathrm{L}$ vs $3.09 \pm 0.10 \mathrm{~g} / \mathrm{L}$ vs $3.81 \pm 0.36 \mathrm{~g} / \mathrm{L}$ ) but only the $1000 \mathrm{ppm}$ dose significantly increase serum LH $(2.10 \pm 0.12 \mathrm{~g} / \mathrm{L}$ vs $2.29 \pm 0.26 \mathrm{~g} / \mathrm{L}$ vs $2.22 \pm 0.37 \mathrm{~g} / \mathrm{L}$ vs $3.18 \pm 0.54 \mathrm{~g} / \mathrm{L}$ ) compared to the control. Also, there was a dose dependent decrease in serum $\mathrm{T}$ compared to the control $(4.62 \pm 0.49 \mathrm{ng} / \mathrm{ml}$ vs $2.87 \pm 0.47 \mathrm{ng} / \mathrm{ml}$ vs $2.10 \pm 0.18 \mathrm{ng} / \mathrm{ml}$ vs $1.57 \pm 0.32 \mathrm{ng} / \mathrm{ml}$ ) following vary doses of $\mathrm{Cd}$ exposure.

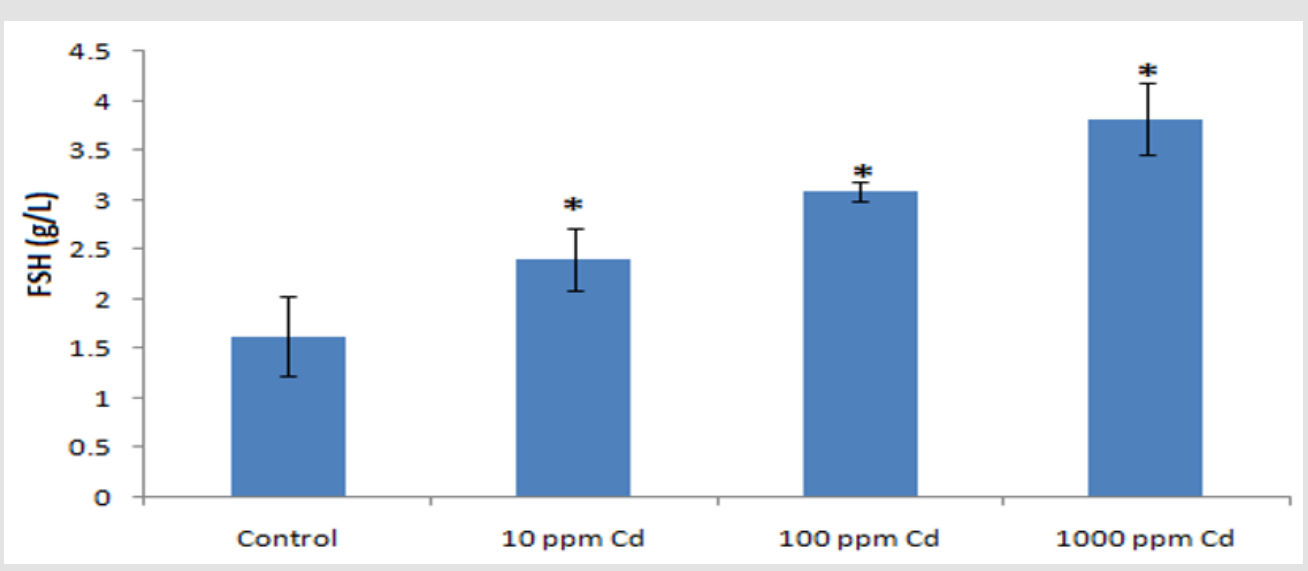

Figure 1: Effect of varying concentrations of $\mathrm{Cd}$ exposure in drinking water on serum FSH level in adult Wistar rats $\left({ }^{*} \mathrm{p}<0.05\right)$. 


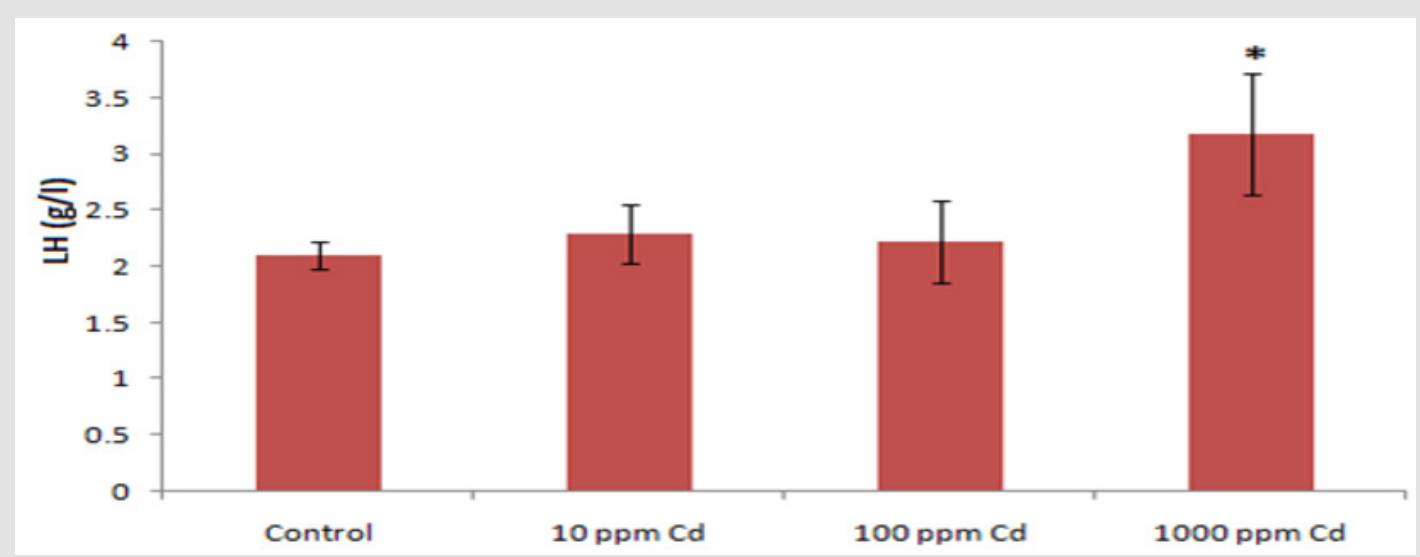

Figure 1: The effect of varying concentrations of $\mathrm{Cd}$ exposure in drinking water on serum LH level in adult Wistar rats (* $\mathrm{p}<0.05)$.

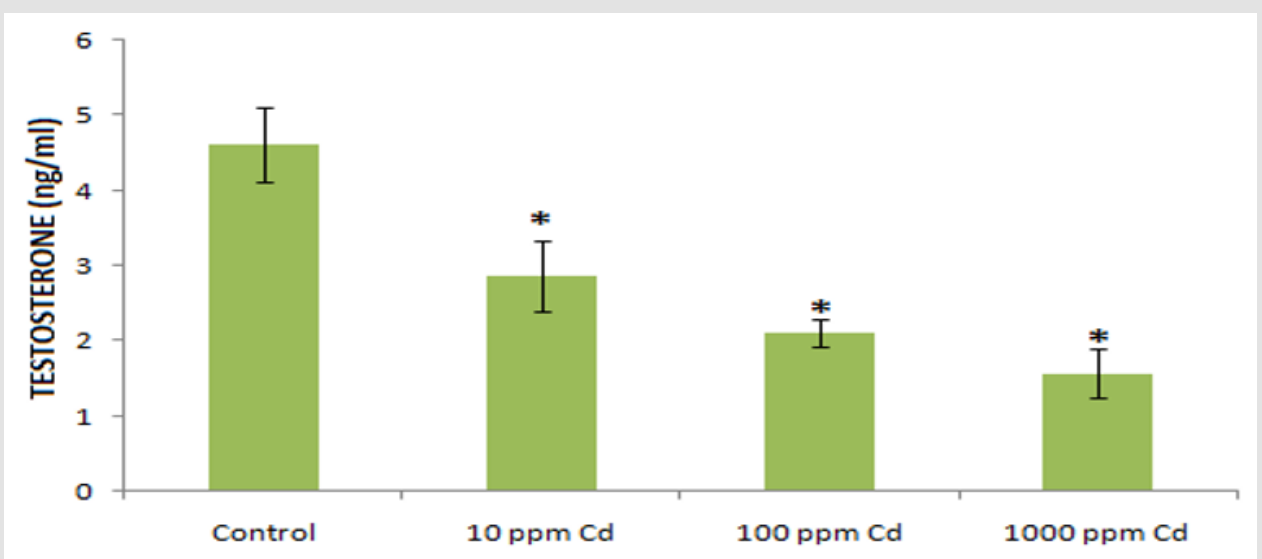

Figure 3: The effect of varying concentrations of $\mathrm{Cd}$ exposure in drinking water on serum testosterone level in adult Wistar rats $\left({ }^{*} \mathrm{p}<0.05\right)$.

Table 1: Effect of varying concentrations of Cd exposure in drinking water on blood Cd level in adult Wistar rats.

\begin{tabular}{|c|c|c|c|c|}
\hline & Control & 10ppm Cd-exposed & 100ppm Cd-exposed & 1000ppm Cd-exposed \\
\hline Blood Cd-level (ppm) & $0.0008 \pm 0.0005$ & $0.0021 \pm 0.0013$ & $0.0153 \pm 0.0085^{*}$ & $0.0298 \pm 0.0204^{*}$ \\
\hline
\end{tabular}

\section{Discussion}

Direct and indirect evidences exist on Cd-induced deleterious health effects through reactive oxygen species following acute overload and chronic toxicity in animals [38] and an early catabolic damage [39]. Blood Cd level is a measure of acute exposure [40] and in the present study, exposure to $100 \mathrm{ppm}$ and $1000 \mathrm{ppm} \mathrm{Cd}$ for 7 days significantly increase blood Cd level. Other studies have also documented increase blood $\mathrm{Cd}$ level following oral exposure. In this instance, Adegoke et al. [41] reported increased blood Cd level higher than those reported in this study following 28 days exposure to $100 \mathrm{ppm}$. However, the increased blood Cd level in the present study showed adequate exposure in the test groups as earlier affirmed by $[42,43]$.

In this study, acute Cd-exposure was observed to be linked with increased production of FSH and LH and inhibition of serum Testosterone. The observed alterations in sex hormones as compared to the control were dose dependent and significant even at the lowest dose except for LH where only the $1000 \mathrm{ppm}$ was. In support of these findings, several studies have documented hormonal alterations following $\mathrm{Cd}$-exposure. $\mathrm{Cd}$ has the potential to affect reproduction and development in several mammalian species [44]. Compared to animal studies, it is claimed that cadmium decreases density, volume, and number of sperms, and increases immature sperm forms [45]. These problems are followed by a defect in spermatogenesis, sperm quality, and secretory functions of accessory glands. Besides, it decreases libido, fertility, and serum testosterone level [46].

This study showed blood Cd level to correlates negatively with serum testosterone but positively with serum LH and FSH. These findings disagree with the studies on Croatian men who had never been occupationally exposed to cadmium $[34,36]$ and in a study 
of Chinese male smelter workers [35] where blood cadmium was positively associated with testosterone. However, in US adult men study, a marginally significant association between cadmium and total testosterone among never smokers and free testosterone among current smokers was observed [4]. The increase stimulation of serum FSH and LH by Cd could indicate $\mathrm{Cd}$ effect on the pituitary gland gonadotrophine hormones and the hypothalamus gronadotropes. However, the stimulated pituitary hormones did not result in the increase in testosterone. This observation showed that though Cd may stimulate pituitary sex hormones, it inhibits sex organ hormone, testosterone. This observation agrees with the report by Chandel and Chand [46] that Cd decrease serum testosterone and may decrease libido and fertility in men. The perceived effect of $\mathrm{Cd}$ on the overall virility of the male should be of grave concern to Health Practitioners and Fertility experts.

Cd exposure induces a dose depended alterations in male sex hormones. Oral $\mathrm{Cd}$ exposure has demonstrated to be a critical determinant of hormone in males. The relationship found between Cd exposure and reduced serum T levels may be of importance for male fertility and continuing investigations will be worthwhile.

\section{References}

1. Nasiadek M, Danilewicz M, Sitarek K, Ewa Świątkowska, Adam Daragó, et al. (2018) The effect of repeated cadmium oral exposure on the level of sex hormones, estrous cyclicity, and endometrium morphometry in female rats. Environmental Science and Pollution Research International 25(28): 28025-28038.

2. ATSDR (2017) Agency for Toxic Substances and Disease Registry, ATSDR's Substance Priority List.

3. Nordberg GF, Bernard A, Diamond GL, John H. Duffus, Paul Illing, et al. (2018) Risk assessment of effects of cadmium on human health (IUPAC Technical Report). Pure and Applied Chemistry 90(4): 755-808.

4. Menke A, Guallar E, Shiels SM, Rohrmann S, Basaria S, et al. (2008) The association of urinary cadmium with sex steroid hormone concentrations in a general population sample of US adult men. BMC Public 8(72).

5. EFSA (2012) European Food Safety Authority, Cadmium dietary exposure in the European population. EFSA Journal 10(1): 2551-2588.

6. EFSA (2009) European Food Safety Authority, Cadmium in food, scientific opinion of the panel on contaminants in the food chain. The EFSA Journal 980: 1-139.

7. Vahter M, Berglund M, Åkesson A, Lidén C (2002) Metals and women's health. Environmental Research 88(3): 145-155.

8. Uetani M, Kobayashi E, Suwazono Y, Kido T, Nogawa K (2006) Cadmium exposure aggravates mortality more in women than in men. International Journal of Environmental Health Research 16(4): 273-279.

9. Nasiadek M, Krawczyk T, Sapota A (2005) Tissue levels of cadmium and trace elements in patients with myoma and uterine cancer. Human and Experimental Toxicology 24(12): 623-630.

10. (1992) WHO IPCS. Environmental health criteria 134 Cadmium. Geneva, World Health Organisation.

11. Stoica A, Katzenellenbogen BS, Martin MB (2000) Activation of estrogen receptor-alpha by the heavy metal cadmium. Molecular Endocrinology 14(4): 545-553.

12. Johnson MD, Kenney N, Stoica A, Hilakivi Clarke L, et al. (2003) Cadmium mimics the in vivo effects of estrogen in the uterus and mammary gland. Nat Med 9: 1081-1084.
13. Brama M, Gnessi L, Basciani S, Nicola Cerulli, cLaura Politi, et al. (2007) Cadmium induces mitogenic signaling in breast cancer cell by an ER $\alpha$ dependent mechanism. Molecular and Cellular Endocrinology 264(1-2): 102-108.

14. Höfer N, Diel P, Wittsiepe J, Wilhelm M, Degen GH (2009) Dose- and route-dependent hormonal activity of the metalloestrogen cadmium in the rat uterus. Toxicology Letters 191(2-3): 123-131.

15. Rider CV, Hartig PC, Cardon MC, Wilson VS (2009) Comparison of chemical binding to recombinant fathead minnow and human estrogen receptors alpha in whole cell and cell-free binding assays. Environmental Toxicology and Chemistry 28(10): 2175-2181.

16. Silva E, Lopez Espinosa MJ, Molina Molina JM, Fernández M, Olea N, et al. (2006) Lack of activity of cadmium in in vitro estrogenicity assays. Toxicology and Applied Pharmacology 216(1): 20-28.

17. Toman R, Massányi P (2002) Changes in the testis and epididymis of rabbits after an intraperitoneal and peroral administration of cadmium. Trace Elem Electrolytes 19: 114-117.

18. Ciarrocca M, Capozzella A, Tomei F, Tomei G, Caciari T (2013) Exposure to cadmium in male urban and rural workers and effects on FSH, LH and testosterone. Chemosphere 90: 2077-2084.

19. De Angelis C, Galdiero M, Pivonello C, Salzano C, Gianfrilli D, et al. (2017) The environment and male reproduction: the effect of cadmium exposure on reproductive functions and its implication in fertility. Reprod Toxicol 1: 105-127.

20. Lukáč N, Massanyi P, Toman R, Trandzik J (2003) Effect of cadmium on spermatozoa motility. Savremena Poljoprivreda 52(3-4): 215-217.

21. Nasiadek M, Danilewicz M, Klimczak M, Stragierowicz J, Kilanowicz A (2019) Subchronic Exposure to Cadmium Causes Persistent Changes in the Reproductive System in Female Wistar Rats. Oxidative Medicine and Cellular Longevity Article ID 6490820, 17 pages.

22. Jiménez Ortega V, Cano Barquilla P, Fernández Mateos P, Cardinali DP, Esquifino AI (2012) Cadmium as an endocrine disruptor: correlation with anterior pituitary redox and circadian clock mechanisms and prevention by melatonin. Free Radic Biol Med 53: 2287-2297.

23. Jiménez Ortega V, Cano Barquilla P, Scacchi PA, Cardinali DP, Esquifino AI (2011) Cadmium-induced disruption in 24-h expression of clock and redox enzyme genes in rat medial basal hypothalamus: prevention by melatonin. Front Neurol 2: 13.

24. Rzymski P, Niedzielski P, Rzymski P, Tomczyk K, Kozak L, Poniedziałek B (2016) Metal accumulation in the human uterus varies by pathology and smoking status. Fertility and Sterility 105(6): 1511-1518.

25. Samuel JB, Stanley JA, Princess RA, Shanthi P, Sebastian MS (2011) Gestational cadmium exposure-induced ovotoxicity delays puberty through oxidative stress and impaired steroid hormone levels. Journal of Medical Toxicology 7(3): 195-204.

26. Wang Y, Wang X, Wang Y, Rong Fan (2015) Effect of cadmium on cellular ultrastructure in mouse ovary. Ultrastructural Pathology 39(5): 324328.

27. Zylber Haran EA, Gershman H, Rosenmann E, Spitz IM (1982) Gonadotrophin, testosterone and prolactin interrelationships in cadmium-treated rats. J Endocrinol 92: 123-130.

28. Laskey JW, Phelps PV (1991) Effect of cadmium and other metal cations on in vitro Leydig cell testosterone production. Toxicol Appl Pharmacol 108: 296-306.

29. Zeng X, Jin T, Zhou Y, Nordberg GF (2003) Changes of serum sex hormone levels and MT mRNA expression in rats orally exposed to cadmium. Toxicology 186: 109-118.

30. Apostoli A, Telisman S, Sager PR (2007) Reproductive and Developmental Toxicity of Metals. In Handbook on the Toxicology of Metals Volume 12. Third edition. Edited by: Nordberg GF, Fowler BA, Nordberg M and Friberg LT. Amsterdam, Academic Press Elsevier. 213-249. 
31. Mason HJ (1990) Occupational cadmium exposure and testicular endocrine function. Hum Exp Toxicol 9: 91-94.

32. Zeng X, Jin T, Buchet JP, Jiang X, Kong Q et al. (2004) Impact of cadmium exposure on male sex hormones: a population-based study in China. Environ Res 96: 338-344.

33. Akinloye O, Arowojolu AO, Shittu OB, Anetor JI (2006) Cadmium toxicity: a possible cause of male infertility in Nigeria. Reprod Biol 6: 17-30.

34. Telisman S, Cvitkovic P, Jurasovic J, Pizent A, Gavella M, et al. (2000) Semen quality and reproductive endocrine function in relation to biomarkers of lead, cadmium, zinc, and copper in men. Environ Health Perspect 108: 45-53.

35. Zeng X, Lin T, Zhou Y, Kong Q (2002) Alterations of serum hormone levels in male workers occupationally exposed to cadmium. J Toxicol Environ Health A 65: 513-521.

36. Jurasovic J, Cvitkovic P, Pizent A, Colak B, Telisman S (2004) Semen quality and reproductive endocrine function with regard to blood cadmium in Croatian male subjects. Biometals 17: 735-743.

37. Gonçalves JF, Nicoloso FT, da Costa P, Farias JG, Carvalho FB, et al. (2012) Behavior and brain enzymatic changes after long-term intoxication with cadmium salt or contaminated potatoes. Food Chem Toxicol 50: 37093718.

38. Patra CR, Rautray KA, Swarup D (2011) Oxidative stress in lead cadmium toxicity and its amelioration. Veterinary Medicine International 11: Article ID 457327 p. 9.

ISSN: 2574-1241

DOI: $10.26717 /$ BJSTR.2020.29.004763

Otamere HO. Biomed J Sci \& Tech Res

(C) This work is licensed under Creative

Submission Link: https://biomedres.us/submit-manuscript.php
39. Osifo CU, Iyawe VI (2018) Cadmium Exposure Induces Early Catabolism in Male Wistar Rat Experiment. J Mol Cell Biochem 2(2): 9.

40. Adams SV, Newcomb PA (2014) Cadmium blood and urine concentrations as measures of exposures: NHANES 1999-2010. J Expo Sci Environ Epidemiol 24: 163-170.

41. Adegoke AG, Salami AT, Olaleye SB (2017) Cadmium Exacerbates Acetic Acid Induced Experimental Colitis in Rats. Eur Exp Biol 7(5): 27.

42. Taylor WR (1988) Permeation of barium and cadmium through slowly inactivating calcium channels in cat sensory neurones. J Physiol 407: 433-452.

43. Jin T, Nordberg $M$, Frech $W$, Dumont $X$, Bernard A, et al. (2002) Cadmium biomonitoring and renal dysfunction among a population environmentally exposed to cadmium from smelting in China (ChinaCad). Biometals 15: 397-410

44. Thompson J, Bannigan J (2008) Cadmium: toxic effects on the reproductive system and the embryo. Reprod Toxicol 25: 304-315.

45. Pizent A, Tariba B, Zivkovic T (2012) Reproductive toxicity of metals in men. Arh Hig Rada Toksikol 63: 35-46.

46. Chandel M, Chand JG (2014) Toxic effects of transition metals on male reproductive system: A review. J Environ Occup Sci 3: 204-213. 